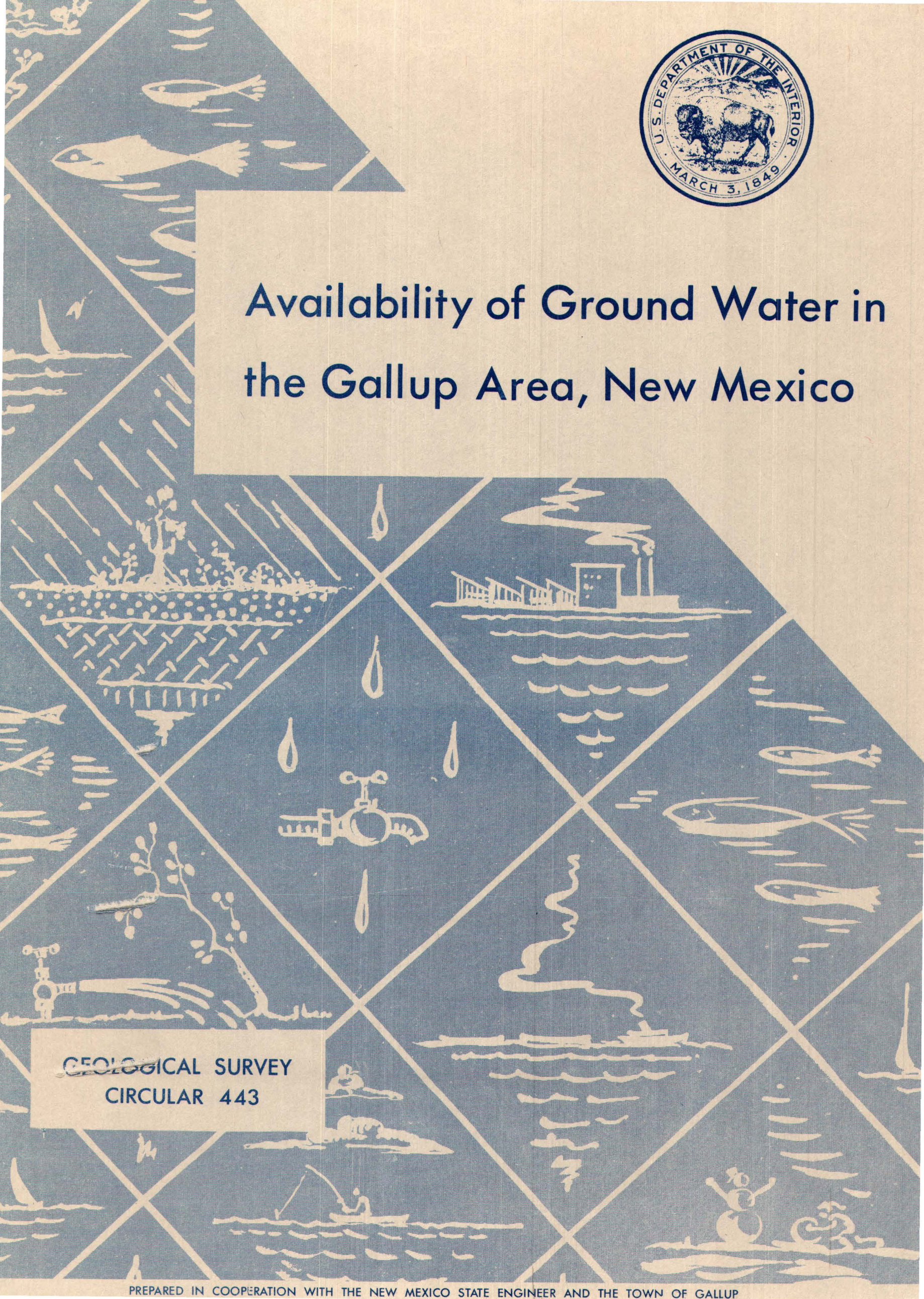




\title{
Availability of Ground Water in the Gallup Area, New Mexico
}

\author{
By S. W. West
}

父

Prepared in cooperation with the New Mexico State Engineer and the town of Gallup

Geological Survey Circular 443 
United States Department of the Interior STEWART L. UDALL, SECRETARY

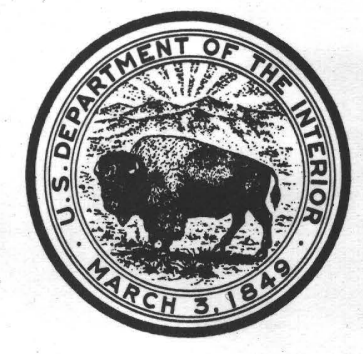

Geological Survey

THOMAS B. NOLAN, Director

\section{父}




\section{CONTENTS}

Page

Abstract .......... 1

Nature of the problem....... 1

Well-numbering system _.......... 4

Water-bearing formations .......... 4

Glorieta sandstone and San Andres

limestone

1
1
4
4

Page

Water-bearing formations-Continued Westwater Canyon member of Morri son formation and Dakota sandstone _. _. 7

Gallup sandstone .............. 8

Conclusions and suggestions .......... 9

Logs of selected wells in the Gallup area _. 12

\section{ILLUSTRATIONS}

Plate 1. Index map of New Mexico and location of wells and springs in the Gallup area _. P.ocket Figure 1. Monthly and yearly deliveries of water to customers and number of meters in

Gallup, New Mexico _...

2. Well-numbering system

Table 1. Specific capacity of wells that tap the Glorieta sandstone and San Andres

limestone in the Gallup area

2. Specific capacity of wells that tap the Westwater Canyon member of the Morrison formation, the Dakota sandstone, or both, in the Gallup area.....

3. Specific capacity of wells that tap the Gallup sandstone in the Gallup area

4. Chemical analyses of waters from wells, springs, and the Puerco River in the

Gallup area

2

\section{TABLES}




\title{
Availability of Ground Water in the Gallup Area, New Mexico
}

\author{
By S. W. West
}

\begin{abstract}
A thick succession of sedimentary rocks (about 6,000 feet) underlies the town of Gallup and crops out nearby. Although all the sedimentary rocks are capable of yielding some water, only a few units of sandstone and limestone yield water in sufficient quantity and of acceptable quality to be considered as sources of large supplies. The five stratigraphic units that are most productive of ground water form three aquifers, as follows: (a) the Glorieta sandstone and San Andres limestone, (b) the Westwater Canyon member of the Morrison formation and the Dakota sandstone, and (c) the Gallup sandstone.
\end{abstract}

The Glorieta sandstone yields only small amounts of water to wells, except where it is intensely fractured. It probably contributes large amounts of water to the overlying, more permeable San Andres limestone by slow vertical leakage over large areas, as water is withdrawn from the San Andres.

The San Andres limestone is discontinuous in the eastern part of the area, wedging out entirely a few miles east of Gallup. Its permeability varies widely because locally the permeability has been greatly increased by fractures and solution channels. On the north flank of the Zuni Mountains, near its outcrop, the San Andres yields as much as 1,100 gpm (gallons per minute) of water to wells. The specific capacity of wells that tap the aquifer formed by this Glorieta sandstone and San Andres limestone ranges from 0.1 to $29 \mathrm{gpm}$ per foot of drawdown.

In general, the water in the Glorieta sandstone and San Andres limestone is hard, because it contains much calcium. Both bicarbonate and sulfate anions are abundant. The chemical quality of the water deteriorates with increasing distance from the outcrop.

The Westwater Canyon member of the Morrison formation and the Dakota sandstone form a single hydrologic unit extending from about 5 miles east of Gallup westward into Arizona. To the east they are separated by shale of the Brushy Basin member of the Morrison formation.

The water-bearing properties of the Westwater Canyon member and the Dakota sandstone are ill defined, because few wells in the area tap either of them exclusively. The specific capacity of wells that tap the Westwater Canyon member, the Dakota sandstone, or both ranges from 0.02 to $2.3 \mathrm{gpm}$ per foot of drawdown.

Water in this aquifer generally contains less that $1,000 \mathrm{ppm}$ (parts per million) of dissolved solids. The concentration of sodium and bicarbonate typically is high, and the concentration of sulfate is high locally.

The Gallup sandstone is the principal aquifer in the immediate vicinity of, and to the north and south of, Gallup. It yields as much as $260 \mathrm{gpm}$ of water to wells; the specific capacity of wells that tap the Gallup sandstone ranges from 0.08 to $4.7 \mathrm{gpm}$ per foot of drawdown. In general, the water in the Gallup sandstone is potable, although in places it yields water high in iron, sulfate, and dissolved solids; the concentration of dissolved solids generally is less than $1,000 \mathrm{ppm}$.

Because the yields of all the formations tested at Gallup are small, the town needs a better source of water. The San
Juan River discharges annually a larger volume of water than is available from any other source in northwestern New Hexico. Gallup has applied for 15,000 acre-feet of San Juan River water a year, an average of $13,400,000$ gpd (gallons per day). This water would be expensive, because about 50 miles of pipeline would be required to transport the water, and it would have to be lifted about 1,000 feet over a high ridge north of town.

Despite the expense involved, at this time the San Juan River seems to offer the most secure long-term supply of water for the Gallup area.

\section{NATURE OF THE PROBLEM}

A rapid increase in population from 1950 to 1955 and a decline in well yields caused the peak daily demand for water in Gallup,N.Mex., to approach the maximum capacity of the well system. As the population increased, the rate of water consumption per capita also increased (fig. 1). To aid in planning, the town of Gallup requested that the U.S. Geological Survey, as a part of its statewide investigation in cooperation with the State Engineer, study the availability of ground water for municipal supply and other uses in the Gallup area. In the summer of 1955 the Geological Survey be gan the study of ground-water resources and geology in the vicinity of Gallup. The project area includes Tps. 13-16 N., Rs. 14-21 W., New Mexico principal meridian (pl. 1). This project was coordinated with a study of the ground-water resources of the Navajo country by the Arizona district of the Geological Survey.

The availability of ground water to supply the town of Gallup was studied by the Hatfield Engineering Co. in 1952..$^{1}$ Before fieldwork by the Geological Survey was concluded in December 1957, an interim report on water wells at Gallup and on the general geology and ground-water supplies in the area was prepared in response to an immediate need

i Hatfield, C. R., 1952, Report on municipal water utility, Gallup, N. Mex.: Albuquerque, N. Mex., Hatfield Engineering Co., 29 p. 
AVAILABILITY OF GROUND WATER IN THE GALLUP AREA, N. MEX.
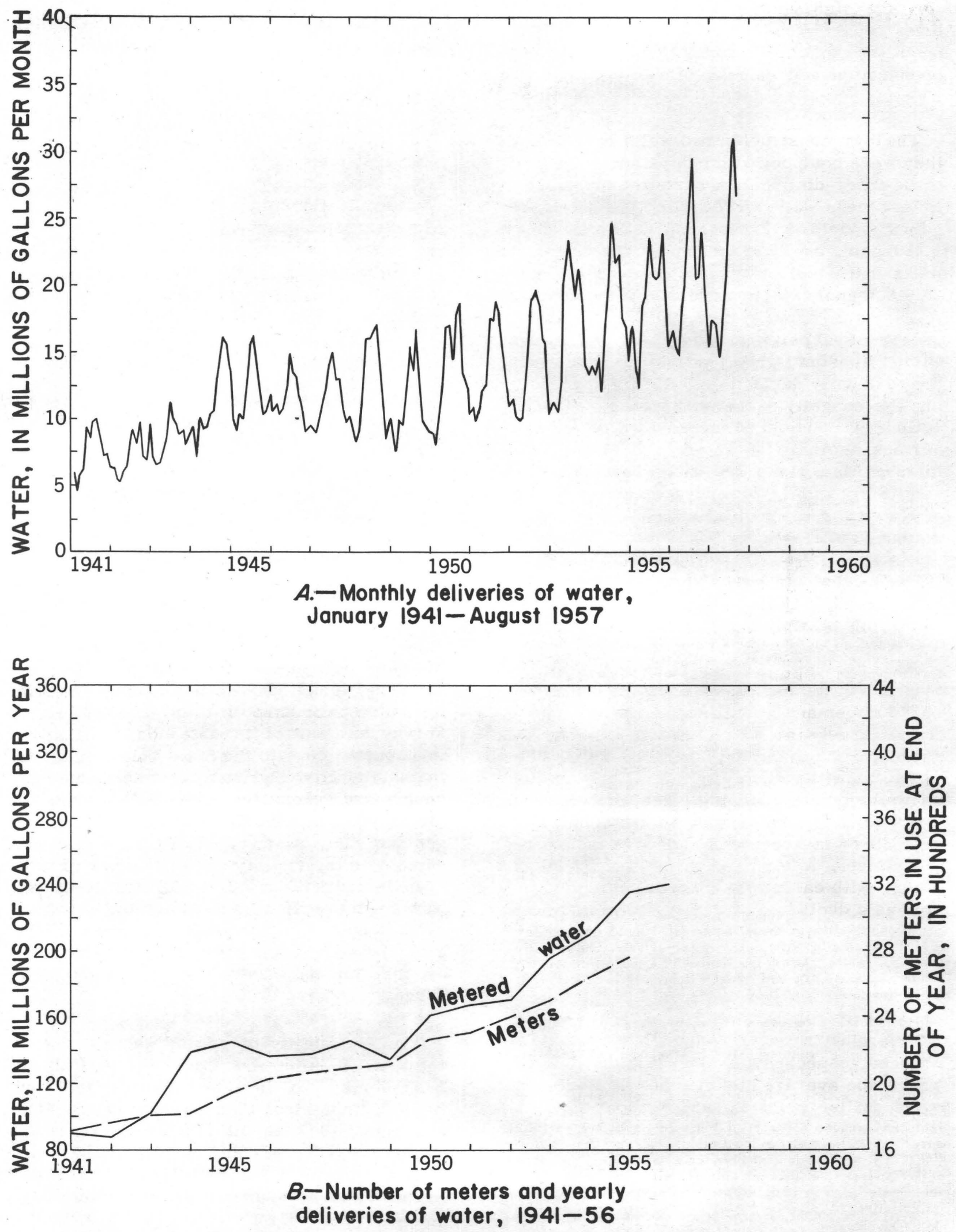

Figure 1. - Monthly and yearly deliveries of water to customers and number of meters in Gallup, New Mexico. 
for such information. ${ }^{8}$ This is the second brief report prepared to serve an immediate need for specific information, pending the preparation and release of a comprehensive report.

The town constructed two wells in 1957, and they were equipped with pumps and connected to the water-distribution system early in 1958. Before these wells were drilled, the combined potential yield of 12 municipal wells was about $1,230 \mathrm{gpm}$, or $1,770,000 \mathrm{gpd}$. The two new wells had a potential yield of about $500 \mathrm{gpm}$ (720,000 gpd), which increased the combined well-system capacity to $2,490,000 \mathrm{gpd}$, an increase of 40 percent. Since 1955 Gallup has gained substantially in population, and again the peak daily demand for water is approaching the capacity of the well system. Prompt action is considered necessary to avert a serious shortage of water in the immediate future. Also, plans are to be formulated as soon as possible to assure an ample supply of water for a much larger city in the more distant future.

Because of the absence of large perennial streams near Gallup, development of ground water for municipal supply has been emphasized. As Gallup has grown, more and more wells have been drilled in and adjacent to town in an attempt to keep production of water ahead of demand. Drilling has been concentrated largely in two well fields, one near the east end of town and the other extending west ward from the center of town. Information on water levels, pumping rates, drawdown in wells during pumping, and amounts of water pumped from each well field are lacking or incomplete. A comparison of current information with early well records, however, indicates a decline of water levels in both well fields and a marked decrease in the yields of several wells, especially of those in the east well field. The decreasing yields are caused largely by declining water levels and dewatering of shallow water-bearing strata. Pumping interference between wells at Gallup is pronounced, especially in the west well field, where the average distance between adjacent wells drilled prior to 1957 is about 450 feet; the two new wells, 15.18.20.211 and 15.18.20.221 , are 1,200 and 1,500 feet from the nearest well. ${ }^{2}$ West, S. W. 1957 , Interim report on water wells, Gallup,
New Mexico: U.S. Geol. Survey open-file rept., 38 p., 2 pls., 8 figs.
The chemical quality of ground water at Gallup also has been a problem (table 4). The water in both well fields contains dissolved solids and sulfate in concentrations near the upper limits (1,000 and $250 \mathrm{ppm}$, respectively) for drinking water recommended by the U.S. Public Health Service. ${ }^{3}$ Also, the water in the east well field generally contains more iron than is recommended (more than 0.3 $\mathrm{ppm}$ ), and the water is hard. The ratio of sodium to calcium and magnesium in water of the west well field is undesirably high for water used for irrigation, including that of lawns.

Because the yields of wells at Gallup are small and the quality of water is only fair, the town is exploring the possibility of obtaining a large supply of good water from dis tant sources. Two means of increasing the water supply are being considered. One is development of a well field near the head of Four Mile Canyon on the Prewitt Ranch, 20 to 25 miles southeast of Gallup, where as much as 1,100 gpm has been pumped from at least one well. The other is construction of facilities to transport water from the San Juan River.

The length of a pipeline to the ground-water reservoir southeast of Gallup would be about half the length of one from the point (the end of a proposed irrigation canal) where the town might obtain water from the San Juan River. Also, storage facilities at the end of the ir rigation canal might be necessary to assure a water supply in the nonirrigation season. A minimum of pumping would be required for delivery of water to Gallup from the groundwater reservoir, because the site is at a higher altitude than the town. Water from the San Juan River would have to be pumped over a high ridge, and the lift might exceed 1,000 feet. The reliability of the ground-water supply on the Prewitt Ranch has not been proved by sustained withdrawal of a large volume of water; however, the San Juan River, on the other hand, discharges annually a larger volume of water than is available from any other source, either surface or ground water, in northwestern New Mexico.

Should the town obtain permission to develop a well field on the Prewitt Ranch, test

\footnotetext{
${ }^{2}$ U.S. Public Health Service, 1946, Drinking water standards: Public Health Repts., v. 61, no. 11, p. 371-384.
} 
wells could be drilled and, if they are successful, a pipeline and treatment plant could be constructed and the water delivered to the municipal system in a relatively short time. Should the town obtain permission to use water from the San Juan River, the water would not be available until the Navajo Dam and irrigation canals were completed, which would take several years. In the meantime the town would have to be supplied with water from wells.

To aid in planning, the most productive geologic formations, their accessibility and yield, and the chemical quality of their waters are described in following sections of this report. Selected information on wells and selected chemical analyses of water are listed in tables $1-4$. The density and distribution of wells in the Gallup area in 1957 are shown on plate 1.

\section{WELL-NUMBERING SYSTEM}

All wells referred to in this report are identified by a location number used by the Geological Survey and the State Engineer for numbering water wells in New Mexico. The location number is a description of the geographic location of the well, based on the system of public land surveys. It indicates the location of the well to the nearest 10acre tract, when the well can be located that accurately. The location number consists of a

Sections within a township R. 18 W.

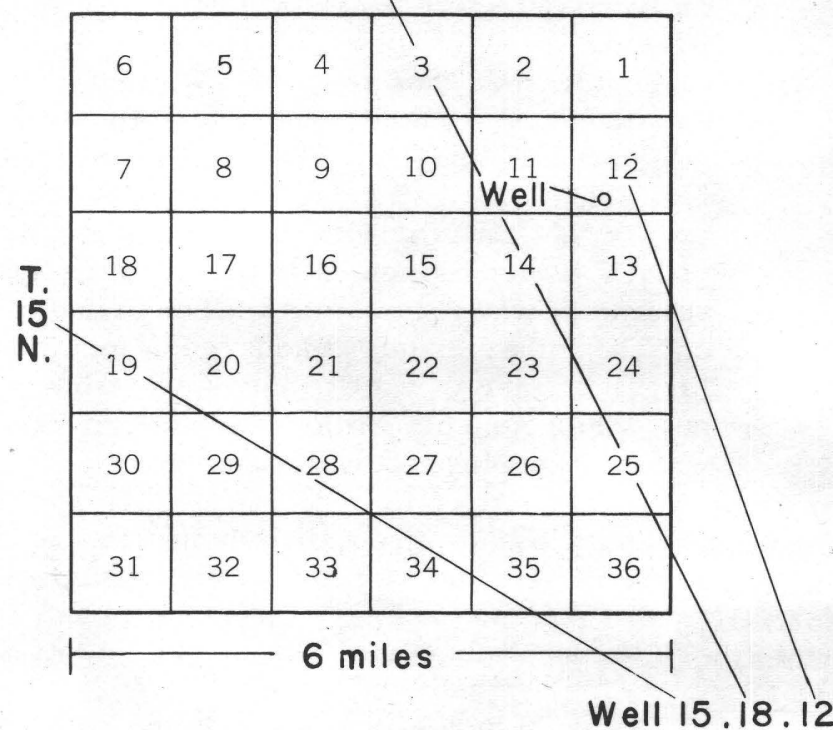

series of numbers corresponding to the township, range, section, and tract within a section, in that order. (See fig. 2.) If a well has not been located closely enough to be placed within a particular section or tract, a zero is used for that part of the number. The letter " $S$ " preceding a location number is used to indicate a spring.

\section{WATER-BEARING FORMATIONS}

The geologic section in the Gallup area includes dense crystalline rocks of Precambrian age and sedimentary rocks ranging in age from Permian to Recent, all of which crop out in the area studied. A generalized stratigraphic section is given below. The Precambrian rocks form the core of the Zuni Mountains and crop out discontinuously from McGaffey southeast ward for about 35 miles. These crystalline rocks form a relatively impervious foundation on which a thick succession of shale, sandstone, and some limestone was deposited. The sedimentary strata dip radially from the central part of the Zuni Mountains.

Erosion has carved a series of concentric as well as radial valleys, slopes, and steep escarpments on the flanks of the Zuni Mountains. Because the shale is more easily - eroded than the sandstone and limestone, in general the valleys are indicative of thick units of shale and the slopes and escarpments are indicative of sandstone or limestone.

\section{Tracts within a section} Sec. 12

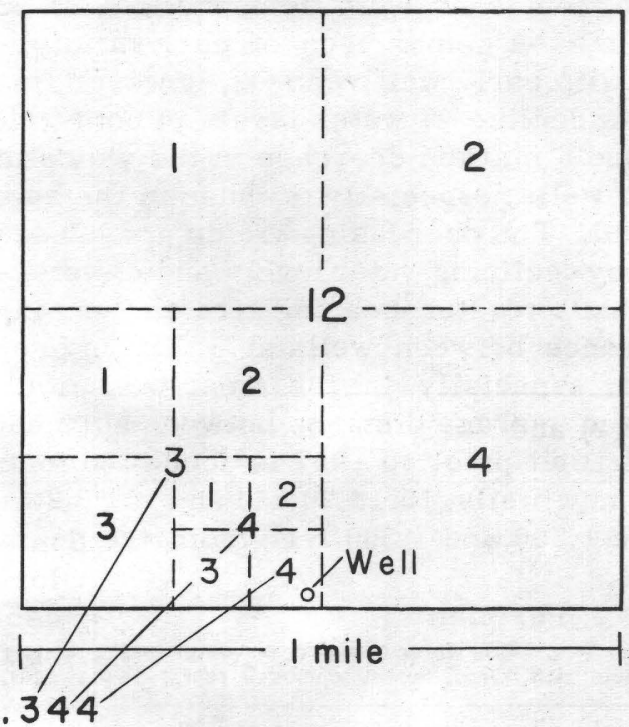

Figure 2. -Well-numbering system. 
Generalized stratigraphic section in the Gallup area, New Mexico

\begin{tabular}{|c|c|c|c|}
\hline Age & & Stratigraphic unit & $\begin{array}{l}\text { Thickness } \\
\text { (feet) }\end{array}$ \\
\hline Quaternary & & Alluvium & $0-200$ \\
\hline Tertiary & & Bidahochi formation & $0-400 \pm$ \\
\hline \multirow[t]{2}{*}{ Late Cretaceous } & \multirow[t]{2}{*}{ 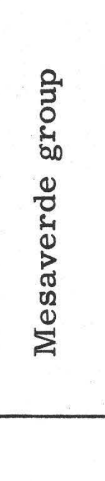 } & $\begin{array}{l}\text { Menefee formation: } \\
\text { Allison member } \\
\text { Cleary coal member } \\
\text { Point Lookout sandstone } \\
\text { Crevasse Canyon formation: } \\
\text { Gibson coal member } \\
\text { Bartlett barren member } \\
\text { Dalton sandstone member } \\
\text { Dilco coal member } \\
\text { Gallup sandstone }\end{array}$ & $\begin{array}{r}0-800 \\
150-175 \\
330-400 \\
240-300 \\
180-350\end{array}$ \\
\hline & & Mancos shale & $500-700$ \\
\hline Early(?) and Late Cretaceous & & Dakota sandstone & $125-250$ \\
\hline \multirow[t]{2}{*}{ Late Jurassic } & & $\begin{array}{l}\text { Morrison formation: } \\
\text { Brushy Basin member } \\
\text { Westwater Canyon member } \\
\text { Recapture member } \\
\text { Zuni sandstone }\end{array}$ & $\begin{array}{r}0-195 \\
100-220 \\
0-60 \\
280-425\end{array}$ \\
\hline & \multirow{2}{*}{ 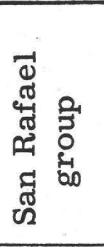 } & $\begin{array}{l}\text { Summerville formation } \\
\text { Todilto limestone }\end{array}$ & $\begin{array}{l}0-60 \\
0-\quad 5\end{array}$ \\
\hline Late and middle Jurassic & & $\begin{array}{l}\text { Entrada sandstone and } \\
\text { Carmel formation, undifferentiated }\end{array}$ & $295-370$ \\
\hline Late Triassic & & $\begin{array}{l}\text { Wingate sandstone: } \\
\text { Lukachukai member } \\
\text { Chinle formation: } \\
\text { Owl Rock member } \\
\text { Petrified Forest member, upper part } \\
\text { Sonsela sandstone bed } \\
\text { Petrified Forest member, lower part } \\
\text { Lower member } \\
\text { Shinarump member }\end{array}$ & $\begin{array}{l}75-360 \\
\\
40 \\
880 \\
20-65 \\
180 \\
235 \\
25\end{array}$ \\
\hline Middle(?) and Early Triassic & . & Moenkopi(?) formation & $25-100 \pm$ \\
\hline Permian & & $\begin{array}{l}\text { San Andres limestone } \\
\text { Glorieta sandstone } \\
\text { Yeso formation } \\
\text { Abo formation }\end{array}$ & 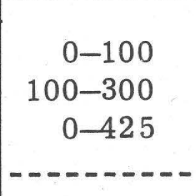 \\
\hline Precambrian & & Crystalline rocks & $\ldots-\ldots-n$ \\
\hline
\end{tabular}


All the sedimentary formations are capable of yielding some water, although only a few units of sandstone and limestone yield water in sufficient quantity and of acceptable quality for consideration as possible sources of large supplies. The three most productive aquifers, consisting of five stratigraphic units, are described in the following sections of the report.

\section{GLORIETA SANDSTONE AND SAN ANDRES LIMESTONE}

The Glorieta sandstone and the overlying San Andres limestone, both Permian in age, form a single hydrologic unit, but one of marked variation in both vertical and horizontal permeability.

The Glorieta sandstone consists of grayishorange-pink to moderate-orange-pink, very fine to fine grained well-sorted quartz sandstone, ranging in thickness from 100 to 300 feet. (See log of well 15.17.12.300,) Generally it is tightly cemented by calcite and silica and is strongly resistant to erosion. Because of severe crustal deformation in the Zuni Mountains, the Glorieta is intensely fractured locally.

The Glorieta sandstone crops out on the north and west flanks of the Zuni Mountains as a caprock on high escarpments and broad dip slopes. In places it forms the walls of deep, narrow canyons. It crops out at the Sheep Laboratory in sec. 7, T. 14 N., R. 16 W. The top of the formation is about 1,800 feet below the land surface at the El Paso Natural Gas Co. plant in sec. 16, T. 15 N., R. 17 W., about 3,700 feet below the land surface in the eastern part of Gallup, and about 4,600 feet below the land surface in the western part of Gallup.

In general the Glorieta sandstone yields only small supplies of water. It is so fine grained and so tightly cemented that storage and movement of water are confined largely to fractures. Although the Glorieta transmits only small amounts of water per square foot of cross section, it probably contributes large amounts of water to the overlying San Andres limestone by slow leakage, as water is withdrawn from the San Andres.

The San Andres limestone consists of lightto medium-gray and pale-brown limestone and limy sandstone 100 feet or less in thickness. (See log of well 15.17.12.300.) The San Andres was exposed to a long period of erosion, during which a karst topography and innumerable solution channels were formed before the overlying Mesozoic rocks were deposited. The San Andres crops out on the flanks of the Zuni Mountains, largely on broad dip slopes, and in places it forms the walls of deep, narrow canyons. The San Andres is discontinuous northwestward from McGaffey and it wedges out entirely a few miles east of Gallup. It crops out at the Sheep Laboratory and the top of the formation is 1,725 feet below the land surface at the Church Rock School in sec. 12, T. 15 N., R. 17 W. It was not identified in wells at the El Paso Natural Gas Co. plant in sec. 16, T. 15 N., R. 17 W., and it has not been observed in outcrops of Permian formations just west of the Arizona boundary.

The permeability of the San Andres limestone has been greatly increased in places by solution channels and fractures which serve as conduits for water. Many wells that tap the San Andres in the Gallup area yield water by natural flow. On the north flank of the Zuni Mountains, near its outcrop, the San Andres yields moderate to large supplies of water to wells. The wells on the Prewitt Ranch tap this formation. Farther from the outcrops the formation yields much less water, probably because ground-water circulation has been less vigorous and, consequently, open channels are not as common. Because the San Andres generally is thin and discontinuous northward and northwestward from Fort Wingate, wells in that area probably will not penetrate more than a few feet of the San Andres, if any.

The specific capacity (yield of water, in gallons per minute per foot of drawdown) of some wells that tap the Glorieta sandstone and San Andres limestone are listed in table 1.

The Glorieta sandstone and San Andres limestone are recharged by infiltration of precipitation and runoff on the outcrops. The annual volume of recharge cannot be determined readily, but recharge to the dense Glorieta sandstone necessarily is small. Recharge to the San Andres limestone may be large locally, but not generally. 
Table 1.- Specific capacity of wells that tap the Glorieta sandstone and San Andres limestone in the Gallup area

\begin{tabular}{|c|c|c|c|c|c|}
\hline Well no. & $\begin{array}{c}\text { Date of } \\
\text { measurement }\end{array}$ & $\begin{array}{l}\text { Duration } \\
\text { of test } \\
\text { (hours) }\end{array}$ & $\begin{array}{l}\text { Pumping or } \\
\text { flow rate } \\
\text { (gpm) }\end{array}$ & $\begin{array}{l}\text { Drawdown } \\
\text { (feet) }\end{array}$ & $\begin{array}{c}\text { Specific } \\
\text { capacity } \\
\text { (gpm per foot } \\
\text { of drawdown) }\end{array}$ \\
\hline $\begin{array}{l}13.14 .5 .311 \ldots \\
13.14 .16 .330 \\
14.15 .29 .120 \ldots \\
15.15 .33 .130 \mathrm{~b} \\
15.16 .23 .430 \ldots- \\
15.17 .16 .222 \ldots- \\
15.17 .16 .224 \mathrm{a} \\
15.17 .16 .310 \\
15.17 .24 .440\end{array}$ & $\begin{array}{l}10-28-54 \\
2-\quad 52 \\
9-\quad 56 \\
6-29-55 \\
8-26-55 \\
9-26-55 \\
6-22-56\end{array}$ & 10 & $\begin{array}{c}65 \\
10 \\
1,100 \\
90 \\
2.2 \\
15 \\
45 \\
47 \\
240\end{array}$ & $\begin{array}{r}100 \pm \\
30 \mp \\
38 \\
346 \\
196 \\
200 \\
200 \\
369 \\
157\end{array}$ & $\begin{array}{c}0.65 \pm \\
29.33 \pm \\
.26 \\
.01 \\
.08 \\
.22 \\
.13 \\
1.5\end{array}$ \\
\hline
\end{tabular}

Water is discharged naturally from the Glorieta sandstone and San Andres limestone by vertical leakage into overlying formations and by flow from springs on the flanks of the Zuni Mountains. The flows of Santa Fe spring (S14.16.6.120), Sheep Laboratory spring (S14.16.7.440)., Bear spring (S14.16.8.220), and Fort Wingate spring (S14.16.9.120) probably rise from the San Andres limestone along fault zones.

Development and use of wells near these springs eventually would affect their flow, possibly to the extent of stopping the flow entirely.

The chemical quality of water in the Glorieta sandstone and San Andres limestone varies widely (table 4). In general, the water is hard because it contains much calcium. Among the anions, both bicarbonate and sulfate are abundant. The calcium and bicarbonate content can be reduced by treatment with lime and filtration. The sulfate cannot be removed economically. Generally, the chemical quality of water in the Glorieta and San Andres deteriorates with increasing distance from their outcrops.

\section{WESTWATER CANYON MEMBER OF MORRISON FORMATION AND DAKOTA SANDSTONE}

The Morrison formation of Late Jurassic age, consists of three members in the Gallup area. In ascending order they are the Recapture member, consisting mainly of red and variegated beds of shale; the Westwater Canyon member, consisting mainly of white to red sandstone; and the Brushy Basin member, consisting mainly of light-greenish-gray shale. Only the Westwater Canyon member yields water to wells. The Brushy Basin member wedges out about 5 miles east of Gallup, and from there westward into Arizona the Dakota sandstone of Early(?) and Late Cretaceous age lies directly on the Westwater Canyon member. These two lithologic units form a single hydrologic unit where they are in contact. To the east the relatively impervious shale of the Brushy Basin member separates them into two distinct hydrologic units.

The Westwater Canyon member consists of white to red very fine to coarse-grained partly conglomeratic sandstone and ranges in thickness from 100 to 220 feet. The sand grains are mainly quartz, although grains of feldspar are common to abundant. Much of the feldspar has been altered in place to clay minerals. (See log of well 15.18.20.211.) The Westwater Canyon member is tightly cemented. Fractures in this unit are common, but they are somewhat indistinct in many places.

The Westwater Canyon member crops out in the hogback east of Gallup, in high escarpments trending eastward from the hogback, and in escarpments southwest of Gallup, extending into Arizona. In the eastern part of Gallup the top of the member is about 1,200 feet below the land surface and in the western part, about 2,060 feet.

The water-bearing properties of the Westwater Canyon member are ill defined, because few wells in the Gallup area tap that member exclusively. Its poor sorting and 
Table 2.-Specific capacity of wells that tap the Westwater Canyon member of the Morrison formation, the Dakota sandstone, or both, in the Gallup area

\begin{tabular}{|c|c|c|c|c|c|}
\hline Well no. & $\begin{array}{c}\text { Date of } \\
\text { measurement }\end{array}$ & $\begin{array}{c}\text { Duration } \\
\text { of test } \\
\text { (hours) }\end{array}$ & $\begin{array}{l}\text { Pumping or } \\
\text { flow rate } \\
\text { (gpm) }\end{array}$ & $\begin{array}{c}\text { Drawdown } \\
\text { (feet) }\end{array}$ & $\begin{array}{c}\text { Specific } \\
\text { capacity } \\
\text { (gpm per foot } \\
\text { of drawdown) }\end{array}$ \\
\hline $14.20 .16 .130 \ldots$ & 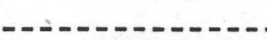 & --- & 6 & 30 & 0.20 \\
\hline $14.21 .26 .220 \ldots$ & $2-15-54$ & 0.5 & 25.6 & 76.5 & .33 \\
\hline $16.14 .16 .140 \ldots$ & $10-\quad 51$ & 2.5 & 11 & 211 & .05 \\
\hline $16.14 .33 .220 \ldots$ & $3-\quad 52$ & .5 & 11.3 & 5 & 2.3 \\
\hline $16.16 .1 .200 \ldots$ & $12-16-48$ & 3 & 7.8 & 490 & .02 \\
\hline
\end{tabular}

tight cementation preclude large yields of water to wells. However, it may transmit large volumes of water locally by slow vertical leakage to the overlying, more permeable Dakota sandstone.

The Dakota sandstone consists of lightgray to buff fine-to medium-grained quartz sandstone and some beds of shale and coal, and ranges in thickness from 115 to 250 feet. Generally, the grains of sand are well sorted and firmly cemented. (See log of well 15.18.20.211.) Fractures are abundant locally, es pecially in places where the formation has been sharply folded.

The Dakota sandstone crops out as a sharp ridge in the hogback east of Gallup and as the caprock in escarpments and on broad slopes eastward from the hogback and southwest of Gallup, extending into Arizona. In the eastern part of Gallup the top of the Dakota is about 750 feet below the land surface and in the western part, about 1,940 feet.

The water-bearing properties of the Dakota sandstone are poorly defined, because few wells in the Gallup area tap it solely. Its fine texture and tight cementation preclude large yields of water, except possibly where fracture systems are well developed.

The combined yield of the Westwater Canyon member of the Morrison formation and the Dakota sandstone generally is small. (See table 2.)

The Westwater Canyon member and the $\mathrm{Da}$ kota sandstone are recharged by infiltration of precipitation and runoff on the outcrops. The annual volume of recharge has not been determined, but it necessarily is small.
Water in the Westwater Canyon member and the Dakota sandstone is discharged naturally through small springs and seeps in outcrop areas, and the water is dissipated by evaporation and transpiration.

Water in the Westwater Canyon member and Dakota sandstone generally contains less than $1,000 \mathrm{ppm}$ of dissolved solids in the Gallup area (table 4). The concentration of sodium bicarbonate typically is high, and that of sodium sulfate is high locally.

\section{GALLUP SANDSTONE}

The Gallup sandstone of Late Cretaceous age consists of light-gray, buff, and pale-red very fine to very coarse grained sandstone and thin to thick beds of shale, and ranges in thickness from 180 to 350 feet. The grains of sand are angular, poorly sorted, and firmly cemented. The grains are mainly quartz, but feldspar is common in some beds. (See log of well 15.18.20.211.)

The Gallup sandstone crops out in small patches in the center of Gallup, as sharp ridges along the west side of the hogback east of Gallup, as a caprock in escarpments and broad dip slopes eastward from the hogback, and in large areas south, southwest, and west of Gallup, extending into Arizona. A relatively thin layer of unconsolidated silt and sand covers the Gallup sandstone in places along the Puerco River valley in the eastern part of Gallup and about 5 miles west of town. South of Gallup a thick unit of unconsolidated sand, silt, and clay of Pliocene age, the Bidahochi formation, overlies the Gallup sandstone. In the western part of town the top of the Gallup sandstone is about 950 feet below the land surface. 
Table 3. - Specific capacity of wells that tap the Gallup sandstone in the Gallup area

\begin{tabular}{|c|c|c|c|c|c|}
\hline Well no. & $\begin{array}{c}\text { Date of } \\
\text { measurement }\end{array}$ & $\begin{array}{c}\text { Duration } \\
\text { of test } \\
\text { (hours) }\end{array}$ & $\begin{array}{c}\text { Pumping rate } \\
\text { (gpm) }\end{array}$ & $\begin{array}{c}\text { Drawdown } \\
\text { (feet) }\end{array}$ & $\begin{array}{c}\text { Specific } \\
\text { capacity } \\
\text { (gpm per foot } \\
\text { of drawdown) }\end{array}$ \\
\hline $14.18 .8 .430 \ldots$ & $5-10-51$ & 3 & 72 & 118 & 0.60 \\
\hline $14.19 .11 .320 \ldots$ & $9-6-56$ & 1.5 & 18.9 & 178 & .11 \\
\hline $14.19 .17 .140 \ldots$ & $3-\quad 54$ & 14 & 34.6 & 78.5 & .43 \\
\hline $15.18 .13 .132 \ldots$ & $3-30-56$ & 1 & 70 & 45.3 & 1.5 \\
\hline $15.18 .14 .144 a$ & $2-13-56$ & 4 & 11 & 45.1 & .24 \\
\hline $15.18 .14 .232 \ldots$ & $2-14-56$ & 5 & 42 & 19 & 2.2 \\
\hline $15.18 .14 .242 \ldots$ & $2-20-56$ & 7 & 147 & 31.5 & 4.7 \\
\hline $15.18 .16 .421 a^{*}$ & $1-\quad 39$ & $\ldots$ & 91.5 & 186 & .49 \\
\hline $15.18 .20 .211^{*} \ldots$ & $9-15-57$ & 24 & 264 & 438 & .62 \\
\hline $15.18 .20 .221^{*} \ldots$ & $5-20-57$ & 24 & 255 & 370 & .69 \\
\hline $15.19 .16 .410 a$ & 1941 & $\ldots$ & 20 & 251 & .08 \\
\hline $15.19 .24 .430 \ldots$ & $2-5-42$ & 3 & 60 & 73 & .82 \\
\hline $15.20 .24 .440 \ldots$ & $8-54$ & & 34 & 47 & .72 \\
\hline 16.20 .9 .400 & $10-29-57$ & 12 & 33 & $176 \pm$ & $.19 \pm$ \\
\hline
\end{tabular}

*Well which taps the Gallup Sandstone mainly but also penetrates the Westwater Canyon member of the Morrison formation and the Dakota sandstone.

The Gallup sandstone, the principal aquifer at Gallup, yields as much as $260 \mathrm{gpm}$ of water to wells in the area (table 3).

The Gallup sandstone is recharged in its outcrop areas by infiltration of precipitation and runoff. Locally, it is recharged by downward percolation of water from the overlying unconsolidated sediments. The annual volume of recharge has not been determined, but declining water levels in the vicinity of well fields indicate that recharge is small.

Water is discharged naturally from the Gallup sandstone through small springs and seeps in the outcrop areas and by vertical or lateral leakage into adjacent unconsolidated deposits. The discharged water is dissipated largely by evaporation and transpiration, although some moves laterally out of the area in the unconsolidated deposits.

Water in the Gallup sandstone varies widely in chemical quality, probably because of variations in the quality of recharge water and of ion exchange between the recharge water and the sandstone and its contained water. Oxidation of iron pyrite associated with coal beds and carbonaceous shale likely contributes to the sulfate in the water. Water in the east well field at Gallup contains 740 to 968 ppm of dissolved solids and 261 to $514 \mathrm{ppm}$ of sulfate. Hardness ranges from 280 to 600 ppm. Water in the Gallup sandstone west of town in T. 15 N., R. 19 W., is of much better chemical quality in all respects.

\section{CONCLUSIONS AND SUGGESTIONS}

The history of ground-water development and production in Gallup shows that yields of all the formations tested are small. The demand for water caused by the normal growth of Gallup repeatedly has threatened to exceed the capacity of the municipal well system. Periodically, it has been necessary to drill more wells. To date, at least 34 wells have been drilled by the town, or drilled by private companies and later transferred to the town. Only 14 of these wells are in use at the present time (March 1960). The yields of the others are so small that their use is impractical. Obviously, Gallup must find a better source of water or continue periodically to drill more wells to keep pace with the normal population growth and decline in yields. Fur thermore, the ground-water supply in the immediate vicinity of Gallup could be depleted eventually.

The San Juan River discharges annually a larger volume of water than is available from any other source, either surface or ground water, in northwestern New Mexico. If Gallup's application for 15,000 acre-feet of water per year (an average of $13,400,000 \mathrm{gpd}$ ) is approved, the town will have available an 
ample supply of water for many years, barring an unforeseen increase in population. This water would be costly, however. A pipeline about 50 miles. long and, possibly, a large storage reservoir at one end of the pipeline would be necessary. Also, the water would have to be lifted vertically about 1,000 feet over a high ridge north of town. Should it become necessary to store water in an open reservoir, evaporation losses would be large. Despite the adverse factors, at this time the San Juan River seems to offer the most secure long-term supply of water for the Gallup area.

If Gallup's application for water from the San Juan River is approved and if facilities to transport the water are justified economically, 10 to 15 years may elapse before the supply can be utilized. First, the Navajo Dam and irrigation system must be completed. In the meantime, the town must be supplied from wells, either by expanding the present well system or by developing a new source of ground water.

A temporary supply of water for at least 10 to 15 years can be obtained by increasing the capacity of the present well system. Pumps having larger capacities and deeper settings than those in some of the wells in the western part of town could deliver much more water. The average specific capacity of wells 15.18.20.211 and 15.18.20.221 (table 3) was $0.65 \mathrm{gpm}$ per foot of drawdown when testedthat is, the pumping rate theoretically would be increased by $0.65 \mathrm{gpm}$ for each foot of additional drawdown. In practice the ratio of yield to drawdown commonly becomes smaller as the drawdown becomes greater. The decrease in ratio of yield to drawdown would be partly offset as the water declined below the top of the Gallup sandstone, at a depth of about 950 feet. When the water level is above the top of the Gallup sandstone, the aquifer is artesian; when the water level declines below the top of the Gallup, gravity drainage of the sandstone would begin and the specific capacity should increase slightly. By lowering the pumping level from 800 to 1,200 feet, the yield of each of these wells should be increased by about $250 \mathrm{gpm}$. Thus, the increment to the water supply would be about 500 gpm, or about 700,000 gpd. The discharge of other wells in the western part of town could be increased, but possibly to a lesser extent.
The water supply could be increased also by drilling additional wells. In the western part of town a well drilled to the base of the Gallup sandstone at a depth of about 1,300 feet should yield about 350 to $450 \mathrm{gpm}(500,000$ to $650,000 \mathrm{gpd}$ ) with a pumping lift of 1,200 feet or less. New wells would have to be at leasst 1,500 feet from other wells to avoid excessive interference.

Should Gallup's application for water from the San Juan River not be granted or should a much greater temporary supply of water be needed, more distant sources of ground water could be developed. A large supply of ground water may be stored in the Glorieta sandstone and San Andres limestone in the vicinity of the Prewitt Ranch, 20 to 25 miles southeast of Gallup. This possibility has not been fully explored by sustained pumping of a large volume of water.

Only one well $(14.15 .29 .120)$ on the Prewitt Ranch, near the head of Four Mile Canyon, has demonstrated a large yield. During a 3hour test this well yielded $1,100 \mathrm{gpm}$ of water with 38 feet of drawdown in water level. The water level undoubtedly would have declined farther, had the same pumping rate been maintained longer. The geologic conditions that make possible this large yield may be restricted to a small area; if so, the large yield of the well could not be sustained indefinitely. A comparison of the yield and the specific capacity of well 14.15.29.120 with that of other wells in the area that tap the Glorieta sandstone artd San Andres limestone suggests that the yield of this well is influenced favorably by local geology. (See table 1.) The nonpumping water level in well 14.15.29.120 declined 16 feet between 1941 and 1956. This decline may have been caused by continuous flow from nearby wells that tap the same aquifer, and perhaps also by the effects of several years of drought.

To appraise the ground-water supply at this locality, two or more test wells would be needed. A well, such as well 14.15.29.120, could be pumped and the effects noted by measuring water levels in the test wells. Test pumping should be continuous at a uniform rate for at least 72 hours. Preferably, at least one of the other wells should be tested by pumping. 
In exploration for a supply of ground water east of Gallup, these facts should be considered: (a) The Glorieta sandstone and San Andres limestone constitute the most productive aquifer in that area; (b) the aquifer is shallowest, its permeability is greatest, and the chemical quality of its water is best near the outcrops on the north slope of the Zuni Mountains. However, a production well should not be drilled within a mile of an outcrop of the aquifer, as wells too near the outcrop would have limited storage to draw on. 


\section{LOGS OF SELECTED WELLS IN THE GALLUP AREA}

The following logs were prepared by S. W. West from examinations of drill cuttings and by stratigraphic correlation with other geologic data. The logs contain color symbols in parentheses following the color of the rock. These numbers are from the "Rock-Color Chart," 1948, dis tributed by the National Research Council, Washington, D. C.

Stratigraphic unit and material

Thickness

(feet)
Depth (feet)

\subsection{7 .12 .300}

McKinley County School at Church Rock. Casing record: 10-inch casing from 0 to 1,965 feet. Casing perforated from 1,725 to 1,965 feet.

Quaternary:

Alluvium:

Sand, light-brown (5YR 6/4), fine to coarse, subrounded to rounded, fairly well sorted; chiefly clear and red-stained quartz, dark minerals rare; pebbles rare...

Upper Triassic:

Wingate sandstone:

Lukachukai member:

Sandstone, light-brown (5YR 6/4), fine-to coarse-grained, subrounded to rounded, fairly well sorted; chiefly clear and red-stained quartz, dark minerals rare, gypsum rare to common; lighter colored and finer grained in lower part

Mudstone, moderate-red (5R $5 / 4)$ to pale-red $(5 \mathrm{R} 6 / 2)$ and lightgreenish-gray (5G 8/1); some silt and very fine to coarse sand...-

Sandstone, light-brown (5YR 6/4), fine-to coarse-grained, subrounded to rounded, fairly well sorted; chiefly clear, frosted, and redstained quartz, dark minerals rare; weakly cemented

Chinle formation:

Owl Rock member:

Samples not recovered

Petrified Forest member, upper part:

Samples not recovered

Mudstone, pale-reddish-brown (10R 5/4), very light gray (N8), and grayish-red (5R 4/2); highly calcareous; some layers are silty; samples not available from $530-590$ feet.

Mudstone, sandy, grayish-red (10R 4/2) flecked with very light gray (N8); sand is chiefly fine to medium, subrounded grains of quartz; some pebbles of mudstone; some gypsum; calcareous ..-

Mudstone, pale-reddish-brown (10R 5/4) and light-gray (N7); compact; calcareous; some light-gray, sandy siltstone

Siltstone, sandy, pale-red (10R 6/2) intermixed with very light gray (N8); sand grains chiefly clear and red-stained quartz, dark minerals common, mica rare to common; weak calcareous cement . .

Mudstone, grayish-red (10R 4/2) flecked with light-gray (N7) and some pale-brown (5YR 5/2); grains of coarse quartz sand rare.-

Samples not available

Sandstone, clayey, very light gray (N8), very fine to fine grained, subangular to subrounded, fairly well sorted; chiefly clear and frosted quartz, dark minerals rare to common; very weak calcareous cement; some grayish-red (10R 4/2) and greenishgray (5GY 6/1) mudstone in lower part 
Stratigraphic unit and material

\begin{tabular}{|c|c}
$\begin{array}{c}\text { Thickness } \\
\text { (feet) }\end{array}$ & $\begin{array}{c}\text { Depth } \\
\text { (feet) }\end{array}$
\end{tabular}

15.17.12.300-Continued

Upper Triassic -Continued

Wingate sandstone -Continued

Chinle formation -Continued

Petrified Forest member, upper part -Continued

Mudstone, grayish-red (10R 4/2), greenish-gray (5GY 6/1), grayish-red-purple (5RP 4/2), and pale-reddish-brown (10R 5/4); some pale-brown ( $5 Y R 5 / 2)$, very fine to fine grained sandstone and very light gray (N8) sandy siltstone Sonsela sandstone bed:

Sandstone, silty, very light gray (N8) to light-brownish-gray (5YR 6/1), very fine to fine grained, subangular to subrounded, fairly well sorted; chiefly clear and frosted quartz, red-and green-stained quartz common, dark minerals rare to abundant; weak calcareous cement; some grayish-red-purple (5RP 4/2) mudstone and siltstone Mudstone, silty, grayish-red (10R 4/2); sand grains rare......Sandstone, silty, very light gray (N8) to light-brownish-gray (5YR 6/1), very fine to medium grained, subangular to subrounded, fairly well sorted; chiefly clear and frosted quartz, dark minerals rare to abundant; weak calcareous cement.....Petrified Forest member, lower part:

Mudstone, grayish-red (5R 4/2), grayish-purple (5P 4/2), white, and light-gray (N7); sand grains rare

Mudstone, grayish-red (10R 4/2) and grayish-red-purple (5RP 4/2) flecked with white and greenish-gray (5GY 6/1)

Mudstone, grayish-red (10R 4/2); some very light-gray (N8), fineto medium-grained, silty sandstone

Mudstone, grayish-red-purple (5RP 4/2) mottled white and very light gray (N8); mica common

Lower member:

Sandstone, silty, light-brownish-gray (5YR 6/1), very fine to fine grained, subangular to subrounded, well sorted; chiefly clear and frosted quartz, dark minerals rare to abundant; some white clay; weak calcareous cement

Mudstone and siltstone, grayish-red (10R 4/2), grayish-red-purple (5RP 4/2), and dark-reddish-brown (10R 3/4); sand grains rare

Sandstone, silty, light-brownish-gray (5YR 6/1) to brownish-gray (5YR 4/1), very fine to fine grained, subangular to subrounded, some crystal faces, well-sorted; chiefly clear quartz, dark minerals rare; weak calcareous cement

Mudstone, grayish-red (10R 4/2), dark-reddish-brown (10R 3/4), and very light gray (N8); mica common

Sandstone, silty, brownish-gray (5YR 4/1), very fine to coarse grained, subangular to subrounded, poorly sorted; frosted and stained quartz; weak calcareous cement

Mudstone, grayish-red (10R 4/2), pale-reddish-brown (10R 5/4), light-greenish-gray (5GY 8/1), and grayish-purple (5P 4/2); some grayish-red siltstone and light-brownish-gray (5YR 6/1), very fine to fine grained sandstone; some pyrite in lower part 
Stratigraphic unit and material

\begin{tabular}{|c|c|}
$\begin{array}{c}\text { Thickness } \\
\text { (feet) }\end{array}$ & $\begin{array}{c}\text { Depth } \\
\text { (feet) }\end{array}$ \\
\hline
\end{tabular}

15.17.12.300-Continued

Upper Triassic - Continued

Chinle formation -Continued

Shinarump member:

Sandstone, light-brownish-gray (5YR 6/1), fine-grained, subangular to subrounded, crystal faces common, poorly to well sorted; some chert, limestone, mudstone, and quartzite pebbles; chiefly clear quartz, very finely to coarsely crystalline pyrite rare to abundant, some carbonaceous material; some mudstone; firmly cemented....-

Middle(?) and Lower Triassic:

Moenkopi formation:

Sandstone, conglomeratic, light-brownish-gray (5YR 6/1), fine-to coarse-grained, subangular to subrounded; pebbles are chert, limestone, mudstone, and quartzite; pyrite common, some hematite; firmly cemented

Mudstone, pale-reddish-brown (10R 5/4) to grayish-red (10R 4/2) and Permian: light-greenish-gray (5GY 8/1); partly sandy; some siltstone........

San Andres limestone:

Limestone, pale-brown (5YR 5/2), finely crystalline, fairly porous; some vein calcite; partly sandy and silty .

Glorieta sandstone:

Sandstone, grayish-orange-pink ( $10 \mathrm{R} 8 / 2)$ to moderate-orange-pink (10YR 8/4), fine-grained, subangular to subrounded, well-sorted; chiefly clear quartz, hematite rare; firmly cemented; weakly . calcareous; partly silty

Samples not available

\subsection{8 .20 .211}

Town of Gallup. Casing record: 18 -inch casing to $100 \mathrm{feet;} 12$-inch casing to 1,319 feet; 8 -inch casing from 1,305 to 2,307 feet.

Quaternary:

Alluvium:

Samples not available

Upper Cretaceous:

Mesaverde group:

Samples not available

Crevasse Canyon formation:

Gibson coal member:

Siltstone, sandy, yellowish-gray (5Y 8/1), poorly sorted; sand chiefly clear quartz, dark minerals common; some fragments of coal; calcareous

Mudstone, medium-gray (N5); grains of clear quartz and dark minerals rare; fragments of coal abundant; weakly calcareous..

Sandstone, clayey, very light gray (N8), fine-grained; chiefly clear and stained quartz, gypsum and dark minerals rare; noncal- 
Stratigraphic unit and material

\begin{tabular}{|c|c|}
\hline $\begin{array}{c}\text { Thickness } \\
\text { (feet) }\end{array}$ & $\begin{array}{c}\text { Depth } \\
\text { (feet) }\end{array}$ \\
\hline
\end{tabular}

15.18.20.211-Continued

Upper Cretaceous -Continued

Mesaverde group - Continued

Crevasse Canyon formation - Continued

Gibson coal member - Continued

Siltstone, light-olive-gray (5GY 6/1), well-sorted, compact, noncalcareous _...........

Sandstone, silty, light-olive-gray ( $5 \mathrm{GY} 6 / 1$ ), poorly sorted, subangular to subrounded; chiefly clear and stained quartz, dark. minerals rare, calcareous

Mudstone, olive-gray (5Y 4/1); limonite stains common, crystalline calcite abundant . . . .

Mudstone, medium-light-gray (N6), noncalcareous; some coal between 180 and 185 feet

Siltstone, medium-light-gray (N6), fairly well sorted; clear quartz grains common, dark minerals rare; noncalcareous ...--

Mudstone, medium-gray (N5), noncalcareous; some coal and some light gray (N7) to very light gray (N8) sandy siltstone .........

Sandstone, clayey, very light gray (N8), fine-grained, well-sorted, subangular to subrounded; chiefly clear and stained quartz, dark minerals common; noncalcareous ..................

Mudstone, olive-gray (5Y 4/1) and medium-light-gray (N6); carbonaceous material common; some coal; noncalcareous ....-

Bartlett barren member:

Sandstone, light-olive-gray $(5 \mathrm{Y} 6 / 1)$ to black, very fine to fine grained, angular to subangular, fairly well sorted; chiefly clear quartz, dark minerals rare; some white clay; noncalcareous; some siltstone -........

Mudstone, medium-light-gray (N6); noncalcareous ............

Sandstone, light-gray (N7), fine to very coarse grained, poorly sorted, subrounded; clear quartz; calcareous ...........

Mudstone, medium-gray (N5); noncalcareous .

Siltstone; medium-light-gray (N6), well-sorted; dark minerals common; calcareous; some coal between 334 and 339 feet ...-.-

Sandstone, clayey, medium-light-gray (N6), very fine to fine grained, poorly sorted, subangular to subrounded; chiefly clear and stained quartz, dark minerals common; coal in lower part -

Mudstone, medium-light-gray (N6) .......................

Sandstone, light-gray (N7), very fine to fine grained poorly sorted, subangular to subrounded; chiefly clear quartz, stained quartz and dark minerals rare to common; some clay; some coal between 384 and 389 feet

Mudstone, medium-light-gray (N6); some coal.......

Siltstone, sandy, medium-light-gray (N6), poorly sorted; sand grains chiefly fine to medium, clear quartz; some mudstone in lower part ...

Sandstone, silty, very light gray (N8), very fine to fine grained, poorly sorted; chiefly clear quartz, stained quartz and dark minerals rare; calcareous; some coal in lower part ......

Mudstone, medium-dark-gray (N4); carbonaceous material abundant; some coal 
15.18.20.211-Continued

\section{Upper Cretaceous - Continued}

Mesaverde group - Continued

Crevasse Canyon formation - Continued

Bartlett barren member - Continued

Siltstone, light-gray (N7), fairly well sorted; some very fine quartz sand; calcareous

Mudstone, olive-gray (5Y 4/1); carbonaceous material abundant ...

Siltstone, light-olive-gray ( $5 Y$ $6 / 1$ ), fairly well sorted; some very

fine sand; weak calcareous cement

Mudstone, medium-light-gray (N6)

Sandstone, silty, light-olive-gray ( $5 \mathrm{Y} 6 / 1)$, very fine to fine grained, fairly well sorted, subangular to subrounded; chiefly clear quartz, stained quartz common, dark minerals rare, very weak calcareous cement.

Mudstone, medium-gray (N5)

Siltstone, sandy, light-olive-gray ( $5 \mathrm{Y}$ 6/1), poorly sorted; sand grains chiefly clear quartz, stained quartz and dark minerals rare; very weak calcareous cement; some coal between 570 and 575 feet

Sandstone, silty, light-gray (N7), very fine to fine grained, poorly sorted, subangular to subrounded; chiefly clear quartz, carbonaceous material abundant; weak calcareous cement ..........

Mudstone, medium-gray (N6); some carbonaceous material; some coal

Siltstone, light-gray (N7); well sorted in upper part, less well sorted in lower part; some very fine quartz sand, increases in lower part; some light-olive-gray ( 5 Y 6/1) mudstone; some fragments of coal; very weak calcareous cement

Mudstone, light-olive-gray (5Y 6/1) to medium-gray (N5); partly carbonaceous; coal in upper part . . . . . . .

Siltstone, light-olive-gray (5Y 6/1), fairly well sorted; sand chiefly very fine quartz grains, dark minerals rare; calcareous; some coal and mudstone between 725 and 730 feet

Siltstone, medium-light-gray (N6), well-sorted; very weak calcareous cement.

Mudstone, medium-light-gray (N6); partly carbonaceous

Sandstone, silty, light-olive-gray $(5 \mathrm{Y} 6 / 1)$, very fine to fine grained; well-sorted, subrounded; chiefly clear quartz, stained quartz and dark minerals rare; weak calcareous cement

Siltstone, light-olive-gray (5Y 6/1), well-sorted; weak calcareous cement; some coal between 760 and 765 feet and between 785 and 795 feet

Sandstone, silty, light-gray(N7) to medium-dark-gray (N4), very fine to fine grained, fairly well sorted, subangular to subrounded; chiefly clear and frosted quartz, carbonaceous material abundant; calcareous

Siltstone, light-olive-gray (5Y 6/1), well-sorted; mica rare; weak calcareous cement; some coal between 815 and 820 feet 
Stratigraphic unit and material

\subsubsection{1-Continued}

\section{Upper Cretaceous - Continued}

Mesaverde group - Continued

Crevasse Canyon formation - Continued

Dilco coal member -Continued

Sandstone, silty, light-olive-gray ( $5 \mathrm{Y} \mathrm{6/1),} \mathrm{very} \mathrm{fine} \mathrm{to} \mathrm{fine}$ grained, fairly well sorted, subrounded; chiefly clear and frosted quartz, carbonaceous material common, dark minerals rare; some coal.

Mudstone, medium-gray (N5); partly carbonaceous

Sandstone, silty, very light gray (N8), very fine to fine grained, fairly well sorted, subangular to subrounded; chiefly clear quartz, dark minerals rare; some coal between 855 and 860 feet -

Mudstone, medium-light-gray (N6); partly carbonaceous ........

Siltstone, sandy, very light gray (N8), fairly well sorted; sand chiefly very fine to fine quartz grains, stained quartz common; weak calcareous cement; some coal

Sandstone, light-gray (N7), fine-grained, well-sorted, subangular to subrounded; chiefly clear and stained quartz, mica rare; some coal.

Mudstone, medium-gray; partly carbonaceous; some coal........

Sandstone, silty, very light gray (N8), very fine to fine grained, fairly well sorted, subangular to subrounded; chiefly clear quartz, dark minerals common

Mudstone, light-brownish-gray (5YR 6/1) to medium-gray (N5); weakly calcareous.

Siltstone, light-gray (N7), well-sorted, dense

Siltstone, clayey, light-brownish-gray (5YR 6/1), well-sorted; some very fine sand; some coal

Gallup sandstone:

Sandstone, light-brownish-gray (5YR 6/1) and pale-red (10R 6/2), very fine to fine grained, fairly well sorted, subrounded; clear and stained quartz

Sandstone, pale-red (10R 6/2), fine-to coarse-grained, poorly sorted, subangular to subrounded; chiefly clear and red-stained quartz, dark minerals and mica rare

Mudstone, medium-gray (N5); partly carbonaceous; fragments of coal abundant

Sandstone, light-brownish-gray (5YR 6/1), fine to very coarse grained, poorly sorted, angular to subrounded; some crystal faces; chiefly clear and stained quartz, pink feldspar common

Mudstone, medium-light-gray (N6); partly carbonaceous; some coal in lower part

Siltstone, light-olive-gray (5Y 6/1), well-sorted; grains of quartz sand common, mica rare; some coal

Sandstone, light-gray (N7), very fine to coarse grained, poorly sorted, subangular to subrounded; clear and stained quartz; finer grained and silty in lower part

Siltstone, medium-light-gray (N6), well-sorted; mica common 
Stratigraphic unit and material Thickness Depth (feet) (feet)

\subsubsection{1-Continued}

\section{Upper Cretaceous -Continued}

Mesaverde group - Continued

Gallup sandstone - Continued

Sandstone, light-gray (N7), very fine to coarse grained, poorly sorted, angular to subrounded; chiefly clear quartz, mica common

Mudstone, medium-gray (N5); some coal

Sandstone, very light gray (N8), very fine to medium grained, fairly well sorted, subangular to subrounded; chiefly clear and smoky quartz; some white clay; calcareous ...........

Mudstone, medium-gray (N5) to medium-dark-gray (N4); partly carbonaceous; some sandy siltstone

Sandstone, light-olive-gray (5Y 6/1), fine-grained; well-sorted, subangular to subrounded; chiefly clear quartz, stained quartz and dark minerals rare; some silt and pinkish-gray (5YR 8/1) coarse sand in lower part.

Sandstone, light-olive-gray ( $5 \mathrm{Y} 6 / 1$ ), very fine to medium grained, fairly well sorted, subangular to subrounded; chiefly clear quartz, stained quartz common, dark minerals rare; calcareous; some

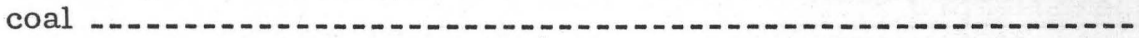

Sandstone, silty, olive-gray (5Y 4/1), very fine to fine grained; chiefly clear quartz, stained quartz and dark minerals common; partly carbonaceous .

Mudstone, medium-light-gray (N6); partly carbonaceous; some coal_

Siltstone, medium-light-gray (N6), fairly well sorted; mica and quartz sand common; calcareous.

Sandstone, light-gray (N7), very fine to fine grained, partly silty, well-sorted, subangular to subrounded; chiefly clear quartz, stained quartz and dark minerals common; mica rare; weak calcareous cement

Mudstone, medium-light-gray (N6) to medium-gray (N5)

Siltstone, medium-light-gray (N6), well-sorted; mica common; partly carbonaceous; some sandstone

Sandstone, very light gray (N8), very fine to coarse grained, mostly well sorted, subangular to subrounded; chiefly clear quartz, dark minerals and mica common

Mancos shale:

Siltstone, medium-gray (N5), well-sorted; partly carbonaceous; grains of quartz sand common

Mudstone, medium-dark-gray (N4); carbonaceous

Sandstone, silty, light-olive-gray ( 5 Y $6 / 1$ ), very fine to fine grained, fairly well sorted, subangular to subrounded; chiefly clear and smoky quartz, dark minerals common; calcareous

Mudstone, medium-gray (N5); carbonaceous ....................

Siltstone, sandy, light-gray (N7), fairly well sorted; sand chiefly quartz, mica common; some coal; weak calcareous cement

Mudstone, medium-dark-gray (N4); partly carbonaceous

Sandstone, silty, very light gray (N8), very fine to fine grained, fairly well sorted, subrounded; chiefly clear quartz, dark minerals common; calcareous 
Stratigraphic unit and material

15.18.20.211-Continued

Upper Cretaceous - Continued

Mancos shale -Continued

Mudstone, medium-dark-gray (N4); coal abundant; pyrite rare.......-

Sandstone, light-olive-gray ( $5 \mathrm{Y} 6 / 1$ ), fine to very coarse grained, poorly sorted, subangular to subrounded; chiefly clear and smoky quartz, dark minerals common, feldspar rare; calcareous

(feet) (feet)

Mudstone, medium-dark-gray (N4); mica common

Sandstone, silty, light-olive-gray (5Y 6/1), very fine to fine grained, fairly well sorted, subangular to subrounded; clear and smoky quartz; calcareous

Siltstone, sandy, very light gray (N8); sand grains very fine, chiefly clear quartz, stained quartz and dark minerals common; calcareous; some fragments of fossil shell material

Mudstone, medium-gray (N5); mica common; some calcite; some siltstone

Sandstone, silty, very light gray (N8), very fine grained, well-sorted, subrounded; clear and smoky quartz

Mudstone, medium-dark-gray (N4) to dark gray (N3); mica and carbonaceous material common; some calcite and pyrite; some siltstone and very fine grained sandstone fairly well sorted; chiefly clear and frosted quartz, dark minerals and fragments of calcite common; calcareous

Mudstone, medium-gray (N5) to medium-dark-gray (N4); partly carbonaceous; mica common, pyrite rare, some fragments of fossil shells; some sandy siltstone, increasing in lower part ......

Lower(?) and Upper Cretaceous:

Dakota sandstone:

Sandstone, silty, light-gray (N7), very fine grained, well-sorted, subrounded to rounded; chiefly clear quartz, pyrite and dark minerals rare; calcareous

Mudstone, medium-gray (N6)

Sandstone, yellowish-gray (5Y 8/1), fine-grained, well-sorted, subangular to roundded; chiefly clear quartz, dark minerals rare; calcareous . . .

Siltstone, sandy, very light gray (N8); partly carbonaceous; sand very fine, chiefly clear quartz, stained quartz and dark minerals rare...-

Sandstone, very light gray (N8), very fine to medium grained, fairly well sorted; subrounded to rounded; chiefly clear quartz, dark minerals rare; some light-gray siltstone, medium-dark-gray mudstone, and coal -

Siltstone, medium-gray (N5), well-sorted; mica and carbonaceous material common; calcareous

Sandstone, very light gray (N8), fine-to coarse-grained, fairly well sorted, angular to rounded, some crystal faces; clear quartz; some fragments of coarse quartz embedded in matrix of white clay . . . -

Sandstone, clayey, white, fine-to coarse-grained, poorly sorted, angular to rounded; clear and stained quartz grains in clay matrix ... 
Stratigraphic unit and material Thickness

\subsubsection{1-Continued}

\section{Upper Jurassic:}

Morrison formation:

Brushy Basin member:

Mudstone and sandy siltstone, greenish-gray (5GY 6/1); some medium-light-gray, very fine to fine grained silty sandstone; calcareous

Siltstone, sandy, greenish-gray $(5 \mathrm{GY} 6 / 1)$; poorly sorted; sand grains are clear and green-stained sand, dark minerals, and mica; some greenish-gray (5GY 6/1) mudstone

Westwater Canyon and Recapture members undifferentiated:

Sandstone, clayey, very light gray (N8), very fine to very coarse grained, some fine gravel, poorly sorted, subangular to rounded; some crystal faces; chiefly clear, frosted, and stained quartz, feldspar common; calcareous.....

Mudstone, sandy, dark-yellowish-brown (10YR 4/2), grayish-brown (5YR 3/2), and greenish-gray (5GY 6/1); sand chiefly very fine to medium grains of quartz

Sandstone, light-gray (N7), fine-to medium-grained, poorly sorted, angular to subrounded; chiefly clear and frosted quartz, feldspar common, dark minerals rare.

Mudstone, greenish-gray (5GY 6/1), grayish-red (5R 4/2), and dark-yellowish-brown (10YR 4/2); partly sandy; sand grains chiefly quartz

Sandstone, clayey, light-gray (N7), very fine to fine grained, poorly sorted, subangular to rounded; chiefly clear and frosted quartz, stained quartz and feldspar common; calcareous

Mudstone, greenish-gray (5GY 6/1), grayish-red (5R 4/2), and darkyellowish-brown (10YR 4/2); partly sandy

Sandstone, silty, medium-gray (N5), very fine grained, fairly well sorted, angular to subrounded; chiefly clear and smoky quartz, dark minerals and mica common, pyrite rare; calcareous; some mudstone in lower part. 
Table 4.-Chemical analyses of waters from weills, springs, and the Puerco River in the Gallup area, McKinley County, N. Mex.

[Chemical constituents are in parts per million. Analyses are by the U.S. Geological Survey]

Location number: See "System of numbering wells" in text for explanation.

Owner or name: The owner or local designation of well, spring, or stream, generally at the time the sample was collected.

Stratigraphic unit: Symbols are in order from oldest to youngest. (See p. 5.)

8, Glorieta sandstone

sa, San Andres limestone

cl, Lower member, Chinle formation mw, Westwater Canyon member, Morrison formation

d, Dakota sandstone

Temperature: The temperature of the water when it was sampled. Some samples were taken from storage tanks, so the temperature of the water was not the same as it was in the well. Iron: Total iron in sample. Iron in solution at time of analysis was generally less.

Dissolved solids: The sum of the analyzed constituents.

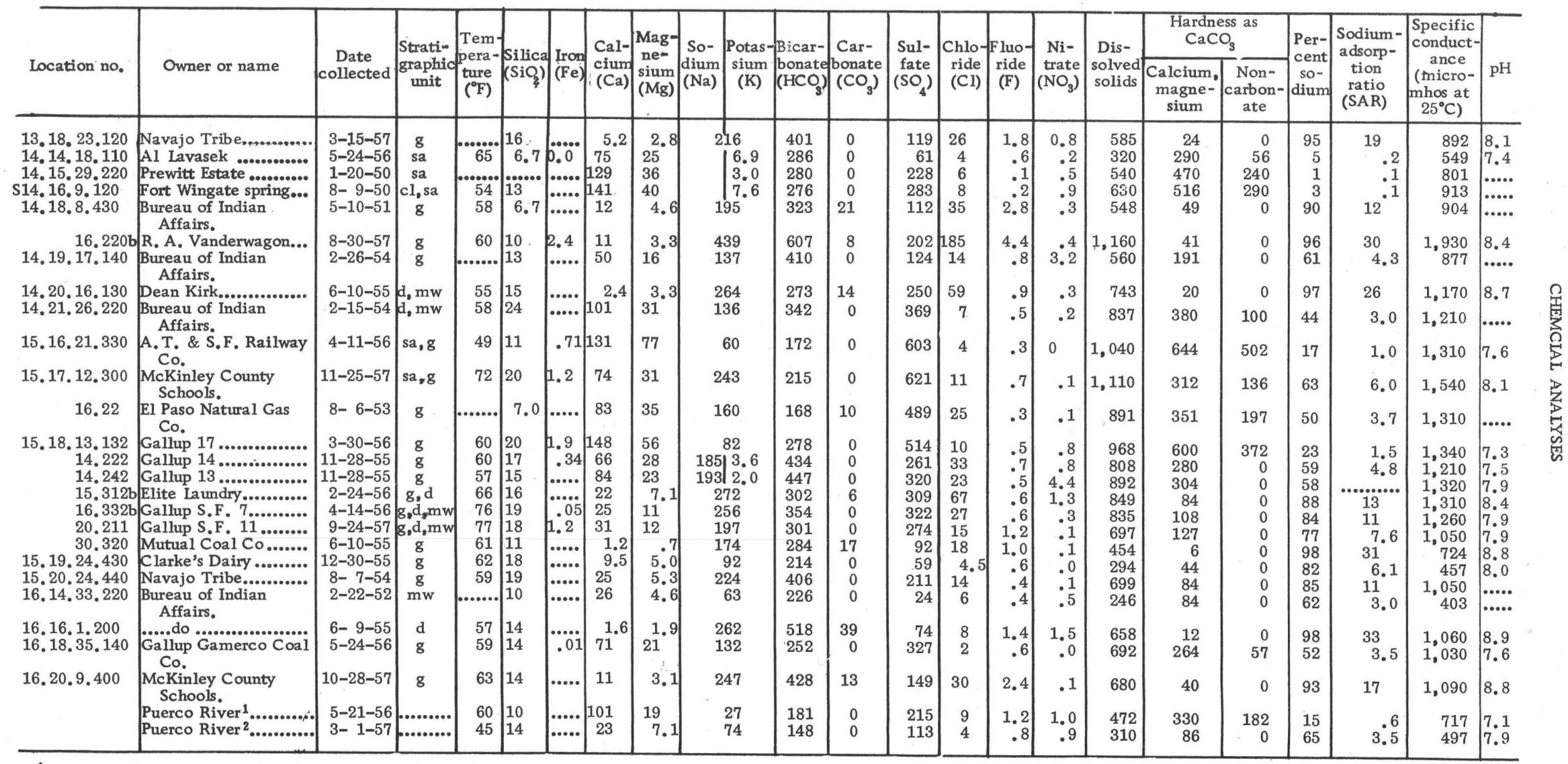

${ }^{1}$ Flow entirely from the North Fork of the Puerco River.

2Flow entirely from the South Fork of the Puerco River. 